\title{
Quality Index Method scheme for whole fresh carapeba (Eucinostomus gula, Quoy \& Gaimard, 1824) stored in ice
}

\author{
Esquema do Método do Índice de Qualidade para carabepa inteira fresca \\ (Eucinostomus gula, Quoy \& Gaimard, 1824) armazenada em gelo
}

\begin{abstract}
Alex Augusto Gonçalves ${ }^{1 *}$, Karoline Mikaelle de Paiva Soares ${ }^{2}$
${ }^{1}$ Universidade Federal Rural do Semi-Árido (UFERSA), Agricultural Sciences Center (CCA), Laboratory of Seafood Technology and Quality Control (LAPESC), Mossoró/RN - Brazil

2 Universidade Federal Rural do Semi-Árido (UFERSA), Biological and Health Sciences Center (CCBS), Laboratory of Industrial Biotechnology, Mossoró/RN - Brazil

\section{*Corresponding Author}

Alex Augusto Gonçalves, Universidade Federal Rural do Semi-Árido (UFERSA), Agricultural Sciences Center (CCA), Laboratory of Seafood Technology and Quality Control (LAPESC), Av. Francisco Mota, 572, Costa e Silva, CEP: 59625-900, Mossoró/RN - Brazil, e-mail: alaugo@ufersa.edu.br, alaugo@gmail.com
\end{abstract}

Cite as: Quality Index Method scheme for whole fresh carapeba (Eucinostomus gula, Quoy \& Gaimard, 1824) stored in ice. Braz. J. Food Technol., v. 20, e2016088, 2017.

Received: July 14, 2016; Accepted: Jan. 13, 2017

\section{Abstract}

Considering the importance of sensory schemes for the evaluation of the freshness of different fish species, and the fact that carapeba (Eucinostomus gula) is an important commercial marine fish species in Northeastern Brazil, the objective of this study was to evaluate the freshness and shelf life of this fish during 18 days stored in ice. Changes during storage were observed according to the sensory evaluation (Quality Index Method - QIM), physicochemical analyses ( $\mathrm{pH}$, total volatile basic nitrogen - TVB-N, and trimethylamine - TMA-N) and microbiological analyses (total mesophilic and psychrotrophic counts). High correlation was found between the Quality Index (QI) and storage time. The microbiological results showed increases in the mesophilic and psychrotrophic counts as from the $9^{\text {th }}$ day of storage. The TVB-N and TMA-N both increased during storage and the $\mathrm{pH}$ value increased slowly. The results suggested that the fresh carapeba is acceptable for consumption when kept in ice for up to 10 days.

Keywords: Fish; Freshness; Quality; Sensory evaluation.

\section{Resumo}

Considerando-se a importância dos esquemas sensoriais para avaliação do frescor das diferentes espécies de peixes e que a carapeba (Eucinostomus gula) é uma importante espécie comercial de peixe marinho na Região Nordeste do Brasil, o objetivo deste estudo foi avaliar o frescor e a vida de prateleira desta espécie durante 18 dias de armazenada em gelo. Alterações durante o armazenamento foram observadas através da avaliação sensorial (Método do Índice de Qualidade - MIQ), das análises físico-químicas ( $\mathrm{pH}$ e nitrogênio das bases voláteis totais - N-BVT, e da trimetilamina - N-TMA) e das análises microbiológicas (contagem total de mesófilos e psicrotróficos). Alta correlação entre o Índice de Qualidade (IQ) e o tempo de armazenamento foi verificada. Os resultados microbiológicos mostraram um aumento da contagem de mesófilos e psicrotróficos a partir do nono dia de armazenamento. O N-BVT e o N-TMA aumentaram durante o tempo de armazenamento, e o pH aumentou lentamente. Os resultados sugerem que o frescor da carapeba permanece aceitável para consumo pelo resfriamento em gelo até 10 dias.

Palavras-chave: Peixe; Frescor; Qualidade; Avaliação sensorial. 


\section{Introduction}

The use of descriptive analyses like the Quality Index Method (QIM) is currently increasing in the sensory analysis of marine products (MARTINSDÓTTIR et al., 2001; GONÇALVES et al., 2015), and in the future is expected to be the main sensory method for research purposes (by researchers in laboratories), industries (for more precise inspection and clear decisions about fish quality) and possibly also in fish auction markets (MARTINSDÓTTIR et al., 2001; SVEINSDÓTTIR et al., 2002).

Carapeba or carapicu (Figure 1), Eucinostomus gula (Quoy \& Gaimard, 1824) is an important commercial marine fish species in Northeastern Brazil (SOARES, 2010), belonging to the family Gerreidae, being characteristic of tropical and subtropical waters. Considering the commercial importance of carapeba in Brazil, the demands for quality and its high perishability, this study aimed to evaluate the freshness and shelf life of this species when stored on ice for 18 days.

\section{Material and methods}

\subsection{Fish source}

Whole fish were obtained directly from fishermen (Areia Branca, RN, Brazil), placed immediately into a clean insulated box containing flaked ice and transported to the Laboratory of Seafood Technology and Quality Control (LAPESC). The time elapsed from the catch to the start of the experiments in the laboratory was no longer than 2 hours. No additives were used on board or after landing. The fish samples $(n=60)$ were washed, divided into three distinct insulated self-draining boxes with flaked ice in layers ( $1: 1$ - fish: ice -20 fishes per box) and maintained in a cold room $\left(5^{\circ} \mathrm{C}\right)$. Melted ice from each box was replaced daily to maintain the proper proportion and suitable cooling for the fish storage $\left(0 \pm 0.1^{\circ} \mathrm{C}\right)$.

\subsection{Development of the QIM scheme}

Following the guidelines for sensory evaluation proposed by Martinsdóttir et al. (2001) for fish species, three people took part in the development and evaluation of

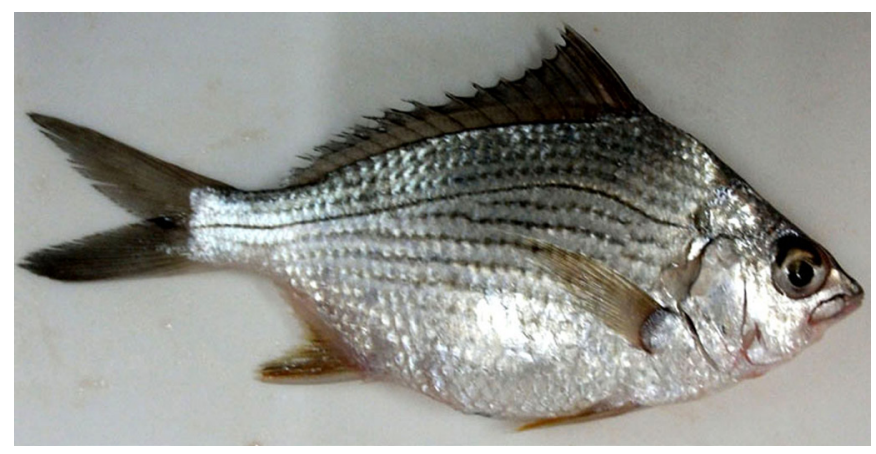

Figure 1. Fresh whole carapeba (Eucinostomus gula, Quoy \& Gaimard, 1824). the QIM scheme. All members had previous training in the development and use of QIM schemes for other seafood species and attended the standards of research ethics. They described the day-to-day changes that occurred during the storage of the carapeba (18 days of storage in flaked ice) and chose the appropriate parameters (Table 1) for the following experiments. All observations of the fish were carried out under standardized conditions following the general guidance for the design of the testing room and testing conditions described in ISO 8589 (ISO, 2007), carried out at the baseline (day zero) and at regular 72-hour intervals (every three days). Photographs of each stage in the sensory evaluation were taken and used to illustrate the quality attributes.

\subsection{Microbial evaluation}

Three samples were taken every 72 hours for total counts of the mesophilic and psychrotrophic bacteria, which were carried out according to the Brazilian Official Analytical Methods (BRASIL, 2003).

\subsection{Physicochemical evaluation}

Total volatile bases nitrogen (TVB-N) and trimethylamine nitrogen (TMA-N) were followed using the LANARA protocol (BRASIL, 1981). The hydrogen potential $(\mathrm{pH})$ was measured using a digital $\mathrm{pH}$ meter (Hayonik ${ }^{\circledR}$ Model FTP905). All analyses were carried out in triplicate every 72 hours.

\subsection{Statistical analyses}

The averages were compared using the Analysis of Variance (ANOVA) and the effects considered significant (by Tukey's test) when the $p$-value $\leq 0.05$. The linear equation (QIM scheme), showing the best fit and the correlation coefficient ( $r$ ) between the $\mathrm{Q}$ l and the storage time in ice, were evaluated. The uncertainty of the prediction of the days on ice from the QI was estimated using the partial least-squares regression (PLS) with full cross-validation.

\section{Results and discussion}

\subsection{QIM scheme}

During the storage period, the carapeba showed gradual and consistent changes for all parameters of the sensory evaluation (Figures 2 and 3). The Quality Index (QI) was obtained from the sum of the scores and ranged from 0-19, for which zero or close to zero represented the best sensory fish quality (freshly caught fish), and 19 completely deteriorated. The QI obtained for each storage day sample formed a linear relationship with time (Figure 2). A high correlation $\left(r^{2}=0.9786\right)$ between the total QI score (for each storage day) and days in flaked ice was obtained, with a slope of 1.0349 , and its evolution could be 
Quality Index Method scheme for whole fresh carapeba (Eucinostomus gula, Quoy \& Gaimard, 1824) stored in ice Gonçalves, A. A.; Soares, K. M. P.

expressed by the equation ( $\mathrm{Q} I=1.0349 \times$ days +1.5825$)$. When applied to the data, the PLS model indicated that the regression model proposed had a mean square of errors (MSE) of approximately 1.8 days (1.755) based on the average QI scores of six samples per storage day (Figure 2), and the measured and predicted values were statistically similar. Since the $\mathrm{Q} I$ is the sum of nine values of the parameter, the measurement error can be assumed

Table 1. Quality Index Method (QIM) scheme for carapeba, Eucinostomus gula.

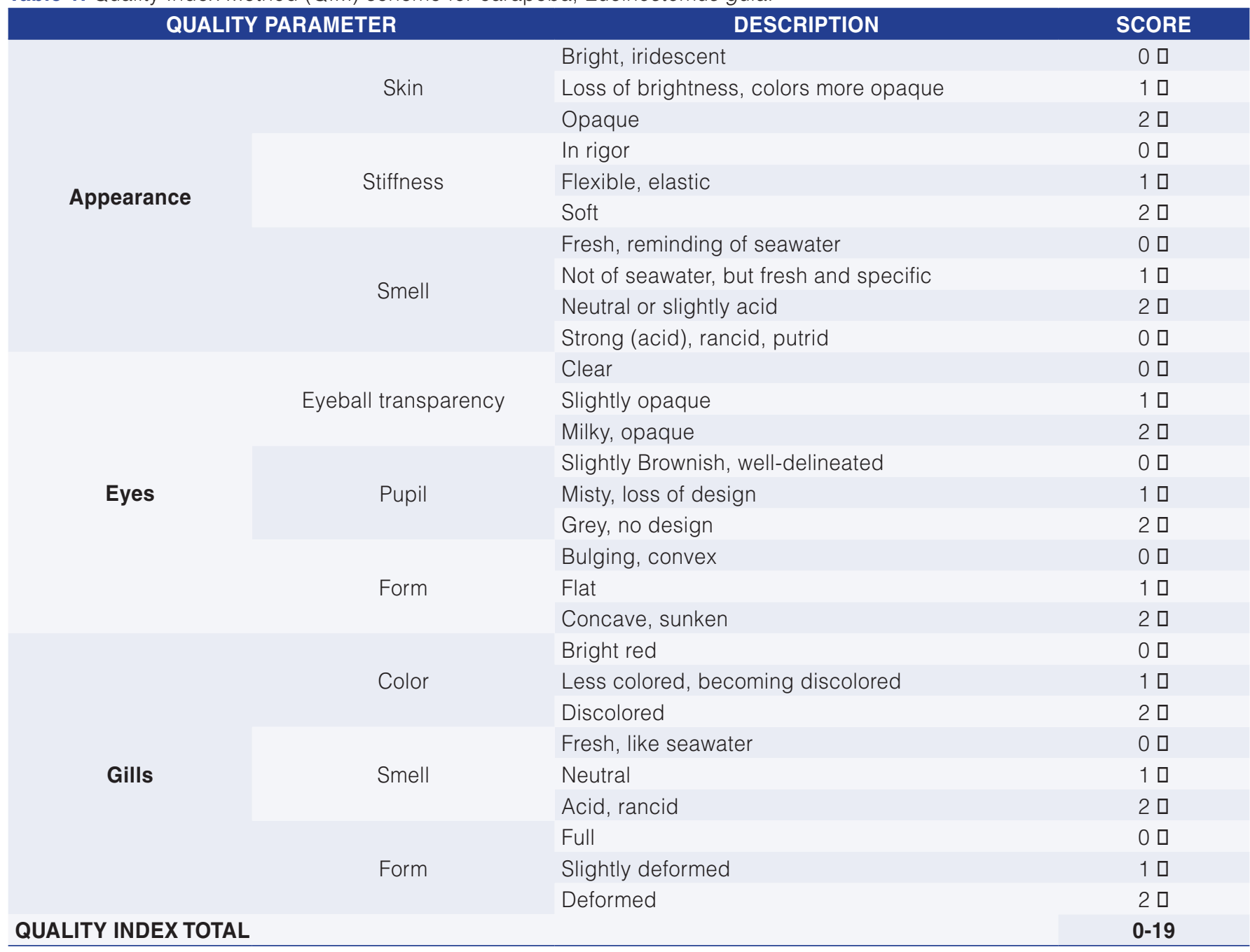
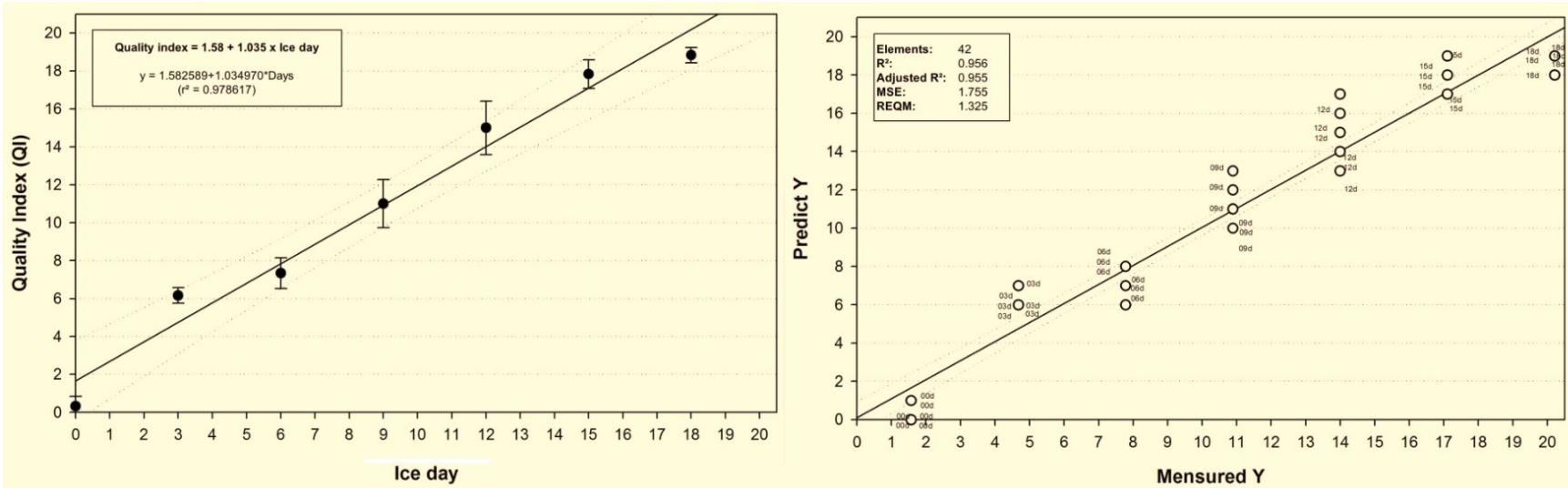

Figure 2. Quality Index (QI) for carapeba $(N=6)$ stored in flaked ice. PLS Regression modelling of the 19 demerit points of the QIM scheme for carapeba stored in flaked ice using full cross-validation: measured vs. predicted $Y$ values. Average QI for each storage day based on an assessment of six carapeba used to predict the storage time in days. 

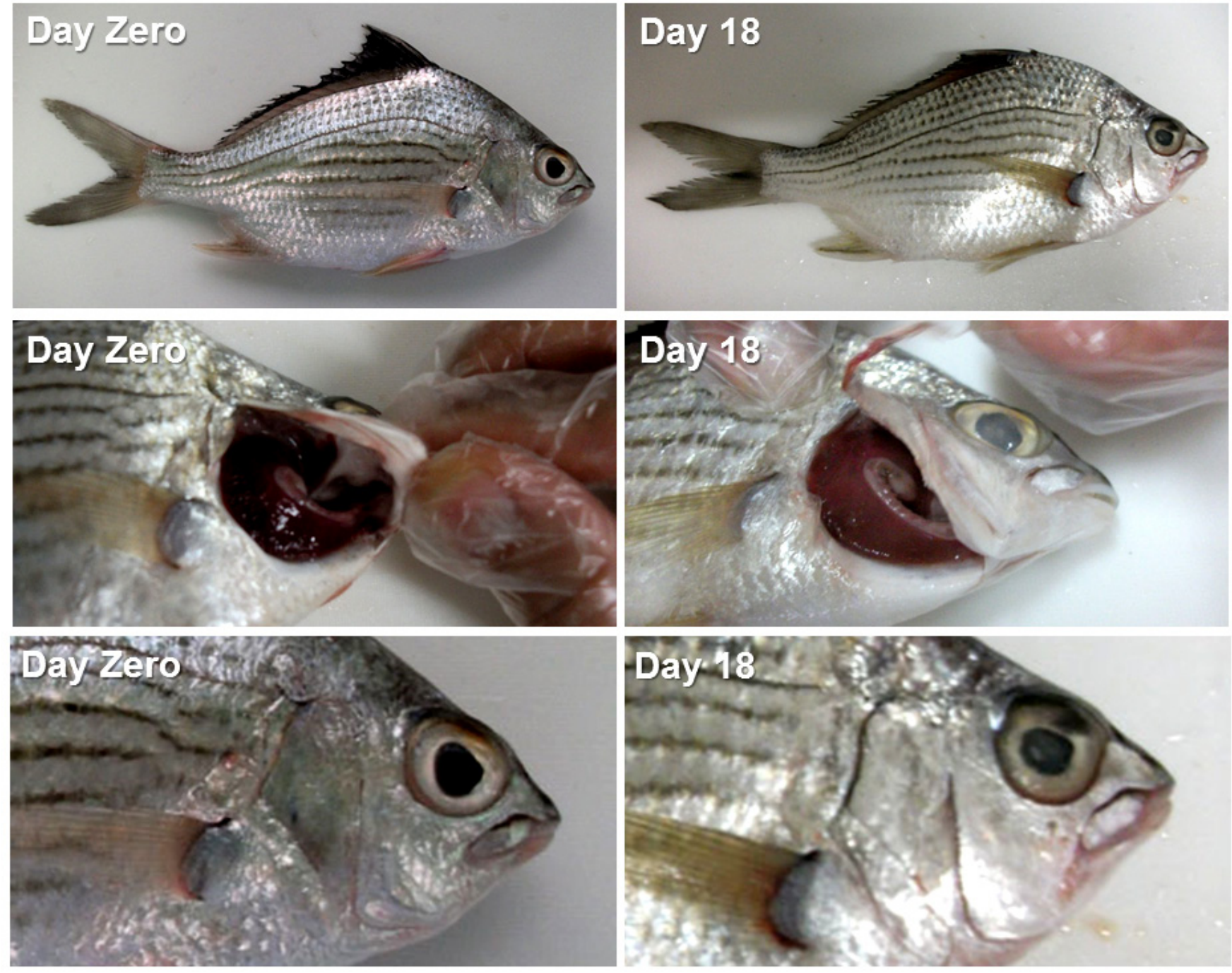

Figure 3. General appearance of the skin, gills, and eyes of fresh carapeba and after 18 days of storage in flaked ice.

to be normally distributed, and the prediction considered as $t$-distributed. The 95\% confidence interval (estimated by MSE $x t(d f=39)=1.755 \times 2.021=3.55)$ may therefore be estimated as approximately 3.6 days. One can therefore assume that the QI based on the average scores of three samples evaluated per storage day could predict the storage time with an accuracy of \pm 1.7 days. A similar correlation was obtained by several authors but the slope was different from the slope observed for other fish species (SVEINSDÓTTIR et al., 2002, 2003; BONILLA et al., 2007), probably due to the biological variation between species and/or to the difference in scores used for the attributes.

One of the possible uses of the QIM values, apart from the estimation of the storage time in ice, is to obtain the remaining shelf-life estimation (SVEINSDÓTTIR et al., 2002, 2003; BORGES et al., 2013, 2014; CYPRIAN et al., 2013; LÓPEZ-GARCÍA et al., 2014; ANDRADE et al., 2015; GONÇALVES et al., 2015), by applying the tables to samples of unknown storage time and subtracting the number of days already spent in ice from the total, up to rejection. These estimations, however, must take into account that in the particular case of carapeba (captured by artisan fisherman), the shorter storage time (10 days) up to rejection (or shelf-life) means all the degradation phases are consequently considerably shorter. It was assumed in the Quality Index Method that the scores for all quality attributes increased with storage time in ice, which is in accordance with the studies of Sveinsdóttir et al. (2003). This was indeed observed, but to a different extent for the different quality attributes, where, with the attribution of demerit points for each separate sensory parameter, it was possible to observe that some carapeba parameters showed early variation (Figure 3 ).

During the later stages, the sensory attributes changed and the odor was described as sour and finally as rotten (day 15). The sour and rotten odors may have originated from short chain fatty acids, alcohols, sulfur compounds and amines generated by microbial activity (SVEINSDÓTTIR et al., 2003), which corroborate with the increase in microorganisms and the TVB-N and TMA-N 
values as from the $10^{\text {th }}$ day of storage. The QIM tables are only the first step in implementation of the QIM system. All the sensory parameters/attributes were considered to be useful to distinguish the freshness of carapeba, and also these parameters were connected with the microbial and physicochemical results to define rejection (end of the shelf life).

\subsection{Microbiological and physicochemical evaluations}

The low total counts found in the early days of storage were due to the flesh of newly caught fish being sterile, since the immune system of fish prevents the bacteria from growing (SVEINSDÓTTIR et al., 2002). However, when the fish dies, the immune system collapses and consequently, during storage, bacteria invade the flesh. The total counts of mesophilic aerobic bacteria in the fish flesh increased with storage time, ranging from $1.81 \times 10^{3} \mathrm{CFU} \mathrm{g}^{-1}(\mathrm{SD}=0.34)$ to $1.92 \times 10^{6} \mathrm{CFU} \mathrm{g}^{-1}$ $(S D=56.57)$ on the $18^{\text {th }}$ day, showing a significant increase mainly from the $15^{\text {th }}$ day $\left(3.8 \times 10^{5} \mathrm{CFU} \mathrm{g}^{-1}-\mathrm{SD}=0.14\right)$ of storage in ice. The psychrotrophic bacteria showed visible colonies as from the $6^{\text {th }}$ day of storage with scores ranging from 0 to $3.0 \times 10^{6} \mathrm{CFU} \mathrm{g}{ }^{-1}$ and with a significant increase as from the $12^{\text {th }}$ day. The total counts of psychrotrophic bacteria showed an initial absence followed by an average of $1.31 \times 10^{3} \mathrm{CFU} \mathrm{g}^{-1}\left(\mathrm{SD}=0.08-6^{\text {th }}\right.$ day), and increasing to $3.05 \times 10^{5} \mathrm{CFU} \mathrm{g}^{-1}(\mathrm{SD}=63.64)$ on the $12^{\text {th }}$ day and $2.97 \times 10^{6} \mathrm{CFU} \mathrm{g}^{-1}(\mathrm{SD}=63.64)$ on the $18^{\text {th }}$ day. Similar values for the total counts of mesophilic bacteria at the beginning of the experiment $\left(2.14 \times 10^{3} \mathrm{CFU} \mathrm{g^{-1 }}\right)$ were found by Baixas-Nogueras et al. (2003), but between the $8^{\text {th }}-10^{\text {th }}$ day they exceeded the legal limit of $1 \times 10^{6} \mathrm{CFU} \mathrm{g}^{-1}$. Fish are notorious for spoiling rapidly even when stored under chilled conditions. The measurement of freshness is therefore an important part of the quality assurance of chill-stored fish, and though sensory methods are generally considered to be the most appropriate for measuring the freshness of fish, there is a role for non-sensory methods (HOWGATE, 2010a).

The carapeba flesh had an initial average $\mathrm{pH}$ value of $6.16 \pm 0.03$ and such a value was maintained up to the $6^{\text {th }}$ day of storage. Between the $6^{\text {th }}$ and $15^{\text {th }}$ days there was an increase up to $6.51 \pm 0.04$, and on the $18^{\text {th }}$ day, the $\mathrm{pH}$ attained 6.96 \pm 0.01 (Figure 2). The TVB-N increased day by day as from the $6^{\text {th }}$ day of storage, but only on the $12^{\text {th }}$ day

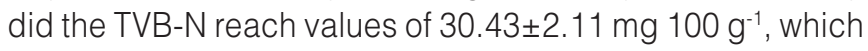
is close to the limit of acceptability of 30 to $35{\mathrm{mg} 100 \mathrm{~g}^{-1}}^{-1}$ (HOWGATE, 2010a), and on the last day (18) the TVB-N

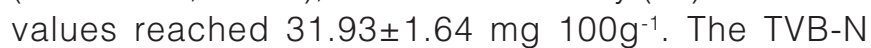
content of typical marine demersal fish at the limit of acceptability as a result of spoilage is around $30 \mathrm{mg}$ nitrogen $100 \mathrm{~g}^{-1}$ of flesh. Along with the TVB-N values, the TMA-N is the most useful index for spoilage in fresh seafood (HOWGATE, 2010a,b), and, in general, they are considered unreliable for the measurement of spoilage during the first 10 days of the chilled storage of several fish species (ÓLAFSDÓTTIR et al., 1997). Although the TVB-N values of all the samples increased throughout the storage period, the TMA-N increased in smaller proportions, i.e., ranging from $1.23 \pm 0.05$ ( $1^{\text {st }}$ day) to $5.92 \pm 0.53 \mathrm{mg} \mathrm{N} 100 \mathrm{~g}^{-1}$ ( $18^{\text {th }}$ day). The determination of these compounds at the time of sensory rejection appears to be adequate to evaluate the spoilage level of fish. In the present work, a significant formation of these volatile compounds was observed. This TVB-N analysis is often used as an index of assessing the shelf life and storage quality of seafood products. The spoilage pattern of fresh seafood generally shows an increase in TVB-N concentration, which closely parallels the bacterial population (HOWGATE, 2010a,b).

\section{Conclusions}

The Quality Index Method showed high linear correlation between the $\mathrm{Q}$ and storage time in ice $(\mathrm{QI}=1.0349 \times$ days in ice $\left.+1.5825 ; r^{2}=0.9786\right)$, making it possible to predict when the fish flesh can be considered fresh and acceptable for consumption, i.e., carapeba can be considered fresh up to the $7^{\text {th }}$ day when stored in ice, and acceptable up to the $10^{\text {th }}$ day, based on the microbiological counts, TVB-N, TMA-N and sensory evaluations.

\section{References}

ANDRADE, S. C. S.; MÁRSICO, E. T.; FRANCO, R. M.; MANO, S. B.; CONTE JR., C. A.; FREITAS, M. Q.; CRUZ, A. G. Effect of storage temperature at the quality index method scheme and shelf-life study of mullet (Mugil platanus). Journal of Food Quality, Malden, v. 38, n. 1, p. 60-70, 2015. http://dx.doi. org/10.1111/jfq. 12123.

BAIXAS-NOGUERAS, S.; BOVER-CID, S.; VECIANA-NOGUÉS, T.; NUNES, M. L.; VIDAL-CAROU, M. C. Development of a quality index method to evaluate freshness in Mediterranean hake (Merluccius merluccius). Journal of Food Science, Malden, v. 68, n. 3, p. 1067-1071, 2003. http://dx.doi.org/10.1111/j.1365-2621.2003. tb08289.x.

BONILLA, A. C.; SVEINSDÓTTIR, K.; MARTINSDÓTTIR, E. Development of Quality Index Method (QIM) scheme for fresh cod (Gadus morhua) fillets and application in shelf life study. Food Control, Amsterdam, v. 18, n. 4, p. 352-358, 2007. http:// dx.doi.org/10.1016/j.foodcont.2005.10.019.

BORGES, A.; CONTE-JUNIOR, C. A.; FRANCO, R. M.; FREITAS, M. Q. Quality Index Method (QIM) developed for pacu Piaractus mesopotamicus and determination of its shelf life. Food Research International, Amsterdam, v. 54, n. 1, p. 311-317, 2013. http:// dx.doi.org/10.1016/j.foodres.2013.07.012.

BORGES, A.; CONTE-JUNIOR, C. A.; FRANCO, R. M.; MÁRSICO, E. T.; FREITAS, M. Q. Quality Index Method (QIM) for the hybrid tambacu (Colossoma macropomum $\times$ Piaractus mesopotamicus) 
Quality Index Method scheme for whole fresh carapeba (Eucinostomus gula, Quoy \& Gaimard, 1824) stored in ice Gonçalves, A. A.; Soares, K. M. P.

and the correlation among its quality parameters. LWT - Food Science and Technology, London, v. 56, n. 2, p. 432-439, 2014.

BRASIL. Ministério da Agricultura. Secretaria Nacional de Defesa Agropecuária. Laboratório Nacional de Referência Animal - LANARA. Métodos analíticos oficiais para controle de produtos de origem animal e seus ingredientes: II. métodos físico químicos. Brasília, 1981.

BRASIL. Ministério da Agricultura, Pecuária e Abastecimento MAPA. Secretaria de Defesa Agropecuária. Instrução normativa $n^{\circ} 62$, de 26 de agosto de 2003. Dispõe sobre os métodos analíticos oficiais para análises microbiológicas para controle de produtos de origem animal e água. Diário Oficial da União, Brasília, DF, 18 set. 2003.

CYPRIAN, O. O.; SVEINSDÓTTIR, K.; MAGNÚSSON, K. H.; ARASONA, S.; JÓHANNSSON, R.; MARTINSDÓTTIR, E. Development of Quality Index Method (QIM) scheme for farmed tilapia fillets and its application in shelf life study. Journal of Aquatic Food Product Technology, Abingdon, v. 23, n. 3, p. 278-290, 2013. http://dx.doi.org/10.1080/10498850.2012.713088.

GONÇALVES, A. A.; PAULA, F. E. R.; LIMA, J. T. A. X. Development of Quality Index Method (QIM) scheme for spiny lobster (Panulirus argus, Latreille, 1804) stored in ice. Food Control, Amsterdam, v. 47, p. 237-245, 2015. http://dx.doi.org/10.1016/j. foodcont.2014.07.010.

HOWGATE, P. A critical review of total volatile bases and trimethylamine as indices of freshness of fish. Part 1. determination. Electronic Journal of Environmental Agricultural and Food Chemistry, Vigo, v. 9, n. 1, p. 29-57, 2010a.

HOWGATE, P. A critical review of total volatile bases and trimethylamine as indices of freshness of fish. Part 2. Formation of the bases, and application in quality assurance. Electronic
Journal of Environmental Agricultural and Food Chemistry, Vigo, v. 9, n. 1, p. 58-88, 2010b.

INTERNATIONAL ORGANIZATION FOR STANDARDIZATION - ISO. ISO 8589: sensory analysis: general guidance for the design of test rooms. Geneva, 2007. p. 1-16.

LÓPEZ-GARCÍA, M. M.; RAMIL-NOVO, L. A.; VÁZQUEZ-ODÉRIZ, M. L.; ROMERO-RODRÍGUEZ, M. A. Development of a Quality Index Method for freshness assessment of thawed Greenland halibut (Reinhardtius hippoglossoides) stored at chilling temperature. Food and Bioprocess Technology, Switzerland, v. 7, n. 6, p. 1847-1852, 2014. http://dx.doi.org/10.1007/s11947-013-1216-3.

MARTINSDÓTTIR, E.; SVEINSDOTTIR, K.; LUTEN, J. B.; SCHELVIS-SMIT, R.; HYLDIG, G. Reference manual for the fish sector: sensory evaluation of fish freshness. The Netherlands: QIM Eurofish, 2001.

SOARES, K. M. P. Desenvolvimento do Método de Índice de Qualidade (MIQ) para avaliar o frescor da carapeba (Eucinostomus gula) armazenada em gelo. 2010. $23 \mathrm{f}$. Monografia (Graduação em Medicina Veterinária)-Universidade Federal Rural do Semi-Árido, Mossoró, 2010.

SVEINSDÓTTIR, K.; HYLDIG, G.; MARTINSDÓTTIR, E.; JORGENSEN, B.; KRISTBERGSSON, K. Quality Index Method (QIM) scheme developed for farmed Atlantic salmon (Salmo salar). Food Quality and Preference, Amsterdam, v. 14, n. 3, p. 237-245, 2003. http:// dx.doi.org/10.1016/S0950-3293(02)00081-2.

SVEINSDÓTTIR, K.; MARTINSDÓTTIR, E.; HYLDIG, G.; JORGENSEN, B.; KRISTBERGSSON, K. K. Application of quality index method (QIM) scheme in shelf-life study of farmed Atlantic salmon (Salmo salar). Journal of Food Science, Malden, v. 67, n. 4, p. 15701579, 2002. http://dx.doi.org/10.1111/j.1365-2621.2002.tb10324.x. 